\title{
Monitoring Effects of Drought on Nitrogen and Phosphorus in Temperate Oak Forests Using Machine Learning Techniques
}

\author{
Jan Kotlarz ${ }^{1}$, Jarosław Siwiński², Marcin Spiralski ${ }^{1}$, Katarzyna Kubiak ${ }^{1 *}$ \\ ${ }^{1}$ Remote Sensing Division, Space Technologies Center, Łukasiewicz Research Network - Institute of Aviation, \\ Al. Krakowska 110/114, Warsaw, 02-256, Poland \\ ${ }^{2}$ Faculty of Civil Engineering and Geodesy, Military University of Technology in Warsaw, \\ ul. gen. Sylwestra Kaliskiego 2, 00-908 Warszawa 46, Poland
}

Received: 28 October 2020

Accepted: 16 August 2021

\begin{abstract}
Pedunculate oak (Quercus robur. L) is a European tree species highly sensitive to drought. If declining symptoms appear they are often detectable at the crown (such as dieback) enabling monitoring using aerial images and remote sensing methods. Here, we analyzed the impact of short and long-term drought on oaks located in western Poland, between the years of 2014 and 2017. We used both leaf nitrogen $(\mathrm{N})$ and leaf phosphorus $(\mathrm{P})$ concentrations measured in the laboratory, aerial images collected in the range of 460-880 $\mathrm{nm}$ and machine learning techniques to estimate nutrient concentrations on the $>4000$ oaks growing on stagnic luvisols in the study area. We determined a negative impact on $\mathrm{N}$ and $\mathrm{P}$ concentrations during both types of drought stress $(-23 \%$ and $-19 \%$ for $\mathrm{N}$ concentration in leaves; $-27 \%$ and $-10 \%$ for $\mathrm{P}$ concentration in leaves). Decreased water availability had inconsiderable impact on N:P values (3\% increase of N:P ratio during short and $7 \%$ decrease of $\mathrm{N}: \mathrm{P}$ ratio during long-term drought stress). We found that the long-term drought impact was spatially diverse, possibly depending on the presence of drainage ditches and competing species.
\end{abstract}

Keywords: drought, oak, plant nutrition, remote sensing, machine learning

\section{Introduction}

Forests are the most vulnerable terrestrial ecosystems in terms of a loss of health due to climate change, which is projected in some climate scenarios - i.e. IPCC RCP 6.0, RCP 8.5 (business as usual) - to be a dominant

e-mail: katarzyna.kubiak@ilot.lukasiewicz.gov.pl stressor on terrestrial ecosystems in the second half of the $21^{\text {st }}$ century [1]. Increasing temperatures and drought stress have negative impacts on forest diversity, structure, function, health and distribution [2], as well as services to humanity (i.e. economic value) [3]. Forest growth rates are significantly correlated to climate [4], and strongly influenced by water availability [5]. Projected changes in climate may occur much faster than the rate at which species and ecosystems are able to adapt [6], and as a result, present forest ecosystems will be affected by new environmental conditions. 
This raises the question of whether ecosystems will be able to adjust, or if their health will decay, resulting in deforestation [7] and changes in species distributions [8]. Increasing temperatures and drought stress effect nutrient availability for forests ecosystems but mechanisms of these phenomena are still not fully understood [9-11]. In general, nitrogen and phosphorus capacity, as well as other nutrients, will increase under elevated $\mathrm{CO}_{2}$ levels [12]. Predicted atmospheric $\mathrm{CO}_{2}$ concentration elevations will result in a warming of an average of $1-3.5^{\circ} \mathrm{C}$ for mid-latitude regions, with more frequent and longer droughts [13]. This plant stress factor strongly affects the growth, gas exchange, cells division, phytohormones production, and the metabolic and transport processes in plants $[6,13]$. An increase in the frequency of drought is likely to reduce the supply and uptake of nutrients and change their redistribution in soils [14-16]. The amount of available $\mathrm{N}$ and $\mathrm{P}$ in soil limit plant growth; accordingly, understanding the $\mathrm{N}$ and $\mathrm{P}$ cycles under new climatic conditions, including forests' response to droughts, becomes very important, because of impact on tree structure and function.

During long-term drought stress, water availability is the main factor that limits plant growth. Metaanalysis of 155 plant observations from 25 studies confirmed that drought stress (DS) generally decreases absolute values of plant $\mathrm{N}(-3.73 \%)$ and $\mathrm{P}(-9.18 \%)$, but increases plant N:P ratio (+ 6.98\%) [17].

DS may enhance $\mathrm{N}$ and $\mathrm{P}$ limitation on plant growth but these effects may be only transient. Furthermore, drought stress-induced enhanced $\mathrm{N}$ and $\mathrm{P}$ limitations on plant growth ( $\mathrm{P}$ more than $\mathrm{N}$ ) are stronger during short-term drought (less than 90 days) [18, 19]. Ectomycorrhises have the ability to increase plants tolerance to drought stress and help plants to survive in condition of deficiency of nutrients [20]. In the natural environment, $\mathrm{P}$ and $\mathrm{N}$ occur together in organic media and their uptake requires a complex set of intracellular enzymes associated with roots and ectomycorrhises. Ectomycorrhises increase and ensure the continuous uptake of nitrogen and phosphorus by plants under the influence of DS. Differences in nutrient intake during water deficit may result from the morphology and physiology of hyphae, mycorrhiza and mycelium, and is dependent on fungal species. Therefore, the study of enzyme activity and species diversity of mycorrhizal fungi is an important research in order to fully understand, predict and model the sustainability of forests in drought conditions [21].

Pedunculate oak (Quercus robur. L) is one of the European tree species more sensitive to drought, with the water limitation immediately showing as decline symptoms of the crown [22]. Oak forest stands in Europe and America were repeatedly reported as sensitive to drought phenomena [23-29]. It is expected that within the next 50-100 years, the mean drought duration in Europe will become considerably longer, the drought period frequency and duration variability will increase and extreme climate events will be more common [30]. In Poland, examples of the local drought impact on forest ecosystems are investigated for the Primeval Forest of Białowieża [31], the Niepołomice oak forest [32], the oak stands of the Krotoszyn Plateau [24] and the Silesian Beskid mountain range area [33]. In 2015, Europe experienced a long-term drought with Central and Eastern regions of the continent, including North Slovakia, Czech Republic and Poland [34] receiving the highest intensity. Meteorological data and literature study from the years 1951-2018 clearly confirmed the occurrence of severe drought phenomena in Poland during 2015.

Total precipitation for that year was $259 \mathrm{~mm}$, which was the lowest in the history of observations for the station at Kalisz (near Krotoszyn Plateau). In contrast, total annual precipitation for the same 1951-2018 period was $502.6 \mathrm{~mm}$, underscoring the significance of the 2015 drought problem.

In 2016 the rainfall was low until July when a higher amount of precipitation was observed (Fig. 2). Regarding the methods of drought classification [35] the drought can be classified as a long-term drought. It can be considered as a 24- month precipitation drought due to the low precipitation in vegetation seasons of 2015, 2016 and 2017 and its reference to the history of observations. In the investigated drought period (2015-2017) the averages of the rainfall stated for $85 \%$ of mean value from 1951-2018 [35].

The effects of drought were the strongest in the Wielkopolska district (west Poland), lasting for 100 days in 2015. This region is the most valuable of oak forest complexes in Poland. The Krotoszyn oak stands are the largest concentration of more than 100-year-old oak stands occurring in large forest complexes and the main species is pedunculate oak (Q. robur L.) [36].

The objective of the study was to evaluate the effect of drought on oak ( $Q$. robur L.) nutrient status expressed by $\mathrm{N}$ and $\mathrm{P}$ content in leaves. For this purpose we analyzed remote sensing and in situ data in machine learning method. We collected data from Krotoszyn Forest District during three vegetation seasons in 2014, 2015 (drought season) and 2017. In-situ data were collected in 2015 and aerial images were collected from 2014, 2015 and 2017. We performed the categorization of the type of drought according to He \& Dijkstra metaanalysis (2014) on the long and short-term drought type and evaluated the impact of both types on nutritional status of oaks [17].

\section{Material and Methods}

\section{Temperature and Precipitation Monitoring}

Meteorological data was obtained from the meteorological data sharing service at the Institute of Meteorology and Water Management-National Research Institute in Warsaw 317 (IMGW-PIB 2018). For the purposes of the analyses the meteorological station 
Kalisz was chosen. It is the closest station with long, uninterrupted history of observation. The distance to the research area is about $40 \mathrm{~km}$. According to historic meteorological data obtained from the Institute of Meteorology and Water Management during the period of 2014-2018 temperature historic pattern was retained [37]. The reference year 2014 is comparable to the mean values for the station. Climate chart were created for the reference year of 2014 and following years with drought - 2015, 2016, 2017, and for 2018. (Fig. 2). Data was compared to the history of observations of 1951-2020 (Fig. 2), as well.

\section{In-situ and Remote Sensing Data}

The $\mathrm{N}$ and $\mathrm{P}$ concentrations in the leaves of 54 oaks $(Q$. robur L.) selected on the experimental area, near Krotoszyn (51.7037 N, 17.5650 E), Wielkopolska region, were investigated in situ during the course of the growing season in 2015. Oak stands cover a total surface of $111.6 \mathrm{ha}$, and it is characterized by stagnic luvisol and forests habitat - fresh type [38]. Common oaks are mainly observed: 123-133 years old on the north and west part of the area and 60-75 years old on the south and west part and 89 years old pine on the east side. All oak heights were found to be between 29-30 m. The average oaks DBH (Diameter at Breast Height) is determined with an accuracy of $1 \mathrm{~cm}$ on the basis of 5-10 measurements made in the stand in places representative for a given division. Main species in the Forest Data Bank 317 [38] are defined as species whose surface area exceeds $5 \%$ of the whole division area.
Species with the area between 1 and 5\% are listed as "admixture species" (Table 1).

Oak leaves were taken from the luminous part of the crowns by alpinists. The leaves were secured in plastic bags and transported at $4^{\circ} \mathrm{C}$ to the laboratory. Chemical analysis of the oak leaves was carried out in the chemical laboratory of the Department of Agricultural Chemistry at the Life Sciences University in Warsaw (N: Kjeldahl method, P: ICP-OES). Soil samples were collected two times during the growing season in 2014 and 2015 (May and July). Each sample was collected under the selected oak tree from a $0.5 \mathrm{~m}$ depth, placed into plastic bags and transferred to the Chemical and Agricultural Station in Warsaw, where the chemical analysis of the soil samples was performed.

In 2014, 2015 and 2017, photogrammetric flights over the HESOFF Project test areas was performed using the QUERCUS.6 multispectral platform [39]. Three optical (460, 550 and $640 \mathrm{~nm})$ and two NIR bands (730 and $820 \mathrm{~nm}$ ) were used to make measurements during the flights. From the collected data, for each year 5-band orthophotomaps were prepared using ArcGIS software, with a $0.25 \mathrm{~m}$ resolution. The images were acquired with a block of non-metric cameras designed for remote sensing applications within the spectral range of 400-1000 $\mathrm{nm}$. This property had no influence on the quality of the data, as the usefulness and interpretative potential of the studies is no worse than in the case of using typical precalibrated cameras [39]. The camera parameters were selected based on the available parameters of the platform, i.e., the geometric and time resolution (particularly important for the
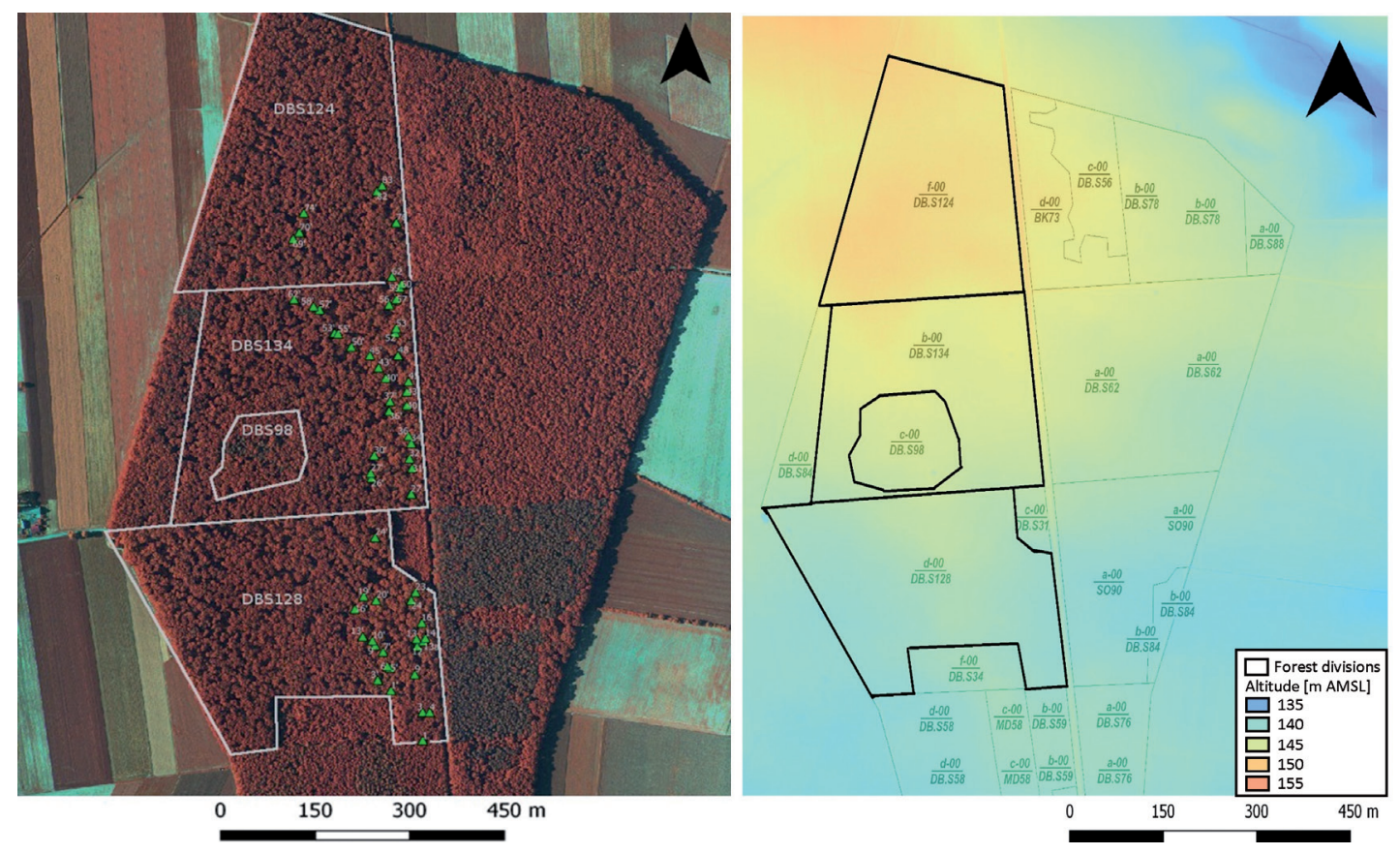

Fig. 1. Left: A total of 54 oaks ( $Q$. robur L.) belonging to the training set of the deep learning algorithm marked on the ortophotomap (false color: $730 \mathrm{~nm}, 550 \mathrm{~nm}, 640 \mathrm{~nm}$ ) obtained from QUERCUS 6 multispectral platform in July 2015. Forest divisions marked. Right: Digital Terrain Model (DTM) created with usage of ALS data. Black polygons state for forest divisions used in the research. Date of acquisition: 2016. 
Table 1. Forest parameters of the forest divisions used for the training set, containing 54 oaks [35], in all forest divisions the soil type was characterized as Stagnic luvisoil.

\begin{tabular}{|c|c|c|c|c|c|}
\hline Division & $\begin{array}{c}\text { Stock } \\
{\left[\mathrm{m}^{3} \mathrm{ha}^{-1}\right]}\end{array}$ & $\begin{array}{c}\mathrm{DBH} \\
{[\mathrm{cm}]}\end{array}$ & $\begin{array}{c}\text { Stand density } \\
{\left[\text { trees ha }{ }^{-1}\right.}\end{array}$ & Main species & Admixture species \\
\hline DBS128 & 375 & 47 & 121,9 & Q. robur $(100 \%)$ & $\begin{array}{c}\text { Carpinus betulus L., Tilia cordata } \\
\text { Mill., Acer pseudoplatanus L. }\end{array}$ \\
\hline DBS98 & 283 & 37 & 159,7 & $\begin{array}{c}\text { Q. robur }(60 \%), \text { P. sylvestris }(20 \%), \\
\text { C. betulus }(20 \%)\end{array}$ & Carpinus betulus L. \\
\hline DBS134 & 385 & 42 & 73.3 & Q. robur $(100 \%)$ & Carpinus betulus L. \\
\hline DBS124 & 375 & 42 & 128.6 & Q. robur $(100 \%)$ & $\begin{array}{c}\text { Carpinus betulus L., Fagus sylvatica } \\
\text { L., Pinus sylvestris L. }\end{array}$ \\
\hline
\end{tabular}

channels at 760 and $850 \mathrm{~nm}$ ). It was decided that the ground sampling distance (GSD) sufficient for remote sensing tests was $0.25 \mathrm{~m}$, with single image dimensions of $1200 \times 804$ pixels.

Due to the high shooting height, the focus was set as infinity. The accuracy of geometric calibration of the orthophotomaps was high, as the total RMSE values of did not exceed $0.1 \mathrm{~m}$ [40].

\section{Tree Crown Separation}

The segmentation of tree crowns consisted of determining single crowns from the differential elevation model nDSM (calculated by subtracting the digital terrain model (DTM) from the digital surface model (DSM). This model was generated from a point cloud established using ArcGIS Desktop software from the matching of the acquired images, using the QUERCUS.6 platform with a GSD of $0.25 \mathrm{~m}$ [41]. The watershed algorithm operating on the nDSM was used for the segmentation of tree crowns [40].

\section{Machine Learning}

Following this, the tree crown segmentations of all 54 oaks with known nitrogen and phosphorus concentrations in the leaves were selected. The average reflectance $I$ and reflectance variability $\sigma$ were calculated for the five bands. This dataset with known $\mathrm{N}$ and $\mathrm{P}$ concentrations was used as the learning set [42-44] in the linear regression with multiple variables (LRMV) algorithm which is one of the machine learning methods [45-50]. The main goal of LRMV method is to find the linear dependencies between reflectance intensity and variability in five optical channels and parameters we want to estimate for all trees, $\mathrm{P}$ and $\mathrm{N}$ concentrations in this particular case. The coefficients form a vector $\theta$ which is our LRMV model. Finally, by applying the gradient descent method with a step precision of $\delta=\sim 3^{*} 10^{-7 \theta}$ models for the $\mathrm{N}$ and $\mathrm{P}$ leaf concentrations was estimated. Nutrients con- centrations $h_{\theta}$ in the tree leaves were estimated using simple equation:

$$
h_{\theta}(\vec{x})=\vec{\theta} \cdot \vec{x}
$$

where $h_{0}$ is calculated nutrient concentration in the tree leaves, $\vec{x}$ is a vector describing tree reflectance and the standard deviation of the reflectance in the five wavelengths, defined as:

$$
\begin{gathered}
\vec{x}=\left[1, \hat{I}_{460 \mathrm{~nm}}, \sigma_{I_{460 \mathrm{~nm}}}, \hat{I}_{550 \mathrm{~nm}}, \sigma_{I_{550 \mathrm{~nm}}}, \hat{I}_{640 \mathrm{~nm}}, \sigma_{I_{640 \mathrm{~nm}}},\right. \\
\left.\hat{I}_{730 \mathrm{~nm}}, \sigma_{I_{730 \mathrm{~nm}}} \hat{I}_{820 \mathrm{~nm}}, \sigma_{I_{820 \mathrm{~nm}}}\right]
\end{gathered}
$$

is the scalar product and $\vec{\theta}$ parameter vector minimize the cost function $\mathrm{J}$ :

$$
J(\vec{\theta})=\frac{1}{2 n} \sum_{\text {tree }=1}^{n}\left(h_{\theta}\left(x_{\text {tree }}\right)-V_{\text {tree }}\right)^{2}
$$

where $n$ is the number of the samples in the learning set (54 here) and $V_{\text {tree }}$ is the in-situ nutrient concentration of the tree.

\section{Nitrogen and Phosphorus Concentration Estimation}

$\mathrm{N}$ and $\mathrm{P}$ concentrations in 2014, 2015 and 2017 were estimated using equation 1 for all trees crowns separated in "Tree crown separation" section above. All trees were categorized into three categories (nutrient concentration deficiency, sufficient concentration, optimal concentration) using nutrient concentrations values described in the report of Dróżdż and coauthors in 2015, N concentration deficiency below $15 \mathrm{~g} / \mathrm{kg}$, sufficient $\mathrm{N}$ concentration between 15 and $25 \mathrm{~g} / \mathrm{kg}$ and optimal N concentration over $25 \mathrm{~g} / \mathrm{kg}$; P concentration deficiency below $1.0 \mathrm{~g} / \mathrm{kg}$, sufficient $\mathrm{P}$ concentration between 1.0 and $3.0 \mathrm{~g} / \mathrm{kg}$ and optimal $\mathrm{P}$ concentration over $3.0 \mathrm{~g} / \mathrm{kg}$ [51] .

\section{Results and Discussion}

Forest stands constitute approximately $82 \%$ of terrestrial biomass and over $50 \%$ of terrestrial biodiversity. They fulfill many key functions in mitigating 
climate changes, provide the nutrient cycling, carbon sequestration, water and air purification, and wood production. Forecasted changes in climate predict an increase in the frequency and elevated drought duration on a global scale, which may affect the availability of nutrients for tree growth and sustainability, productivity, and the function of forest ecosystems [17].

Drought stress, in general, reduces nutrient availability in the soil, uptake by roots, transport from roots to shoots and partitioning in plants because of restricted transpiration rates and impaired active transport and membrane permeability [52-54]. Water stress reduces plant growth by affecting various physiological and biochemical processes, such as photosynthesis, respiration, translocation, ion uptake, carbohydrates, nutrient metabolism and growth promoters $[55,56]$.

The data for year 2015 show that annual precipitation was the lowest in the history of observation (starting in 1951). The rainfall decreased during year 2015 causing severe drought. Its significant increase was observed in 2016. The beginning of 2017 was a period of decreased amount of rainfall, which caused the drought at the beginning of the growing season.
The classification of drought types based on meteorological data included analysis of DS periods with no rainfall and its influence on the amount of $\mathrm{N}$ and $\mathrm{P}$ in vegetation. Impact of short- and long-term drought is presented in a section below.

\section{Nitrogen and Phosphorus Content in Oak Leaves during Short- and Long-Term Drought}

The chemical analysis of the soil samples in July 2014 showed an average $\mathrm{N}$ content of $0.12( \pm 0.10) \mathrm{g} / \mathrm{kg}$ and $\mathrm{P}$ content of $3.14( \pm 2.33) \mathrm{g} / \mathrm{kg}$. The following year, the concentrations of $\mathrm{N}$ and $\mathrm{P}$ were calculated as $0.14( \pm 0.10)$ and $4.3( \pm 3.83) \mathrm{g} / \mathrm{kg}$ soil, respectively. Statistical test for $\mathrm{N}$ content means is 0.77 which is smaller than critical value of t-student test for $p=0.05$ (2.004). Statistical test for $\mathrm{P}$ content means is 0.61 which is also smaller than critical value of t-student test. This indicates that soil amounts for both nutrients were sufficient in 2014 and 2015. Note that data was not obtained from 2017. All of the trees selected for the training set for the deep learning algorithm belong to the north-west part of the stand (Fig. 1),
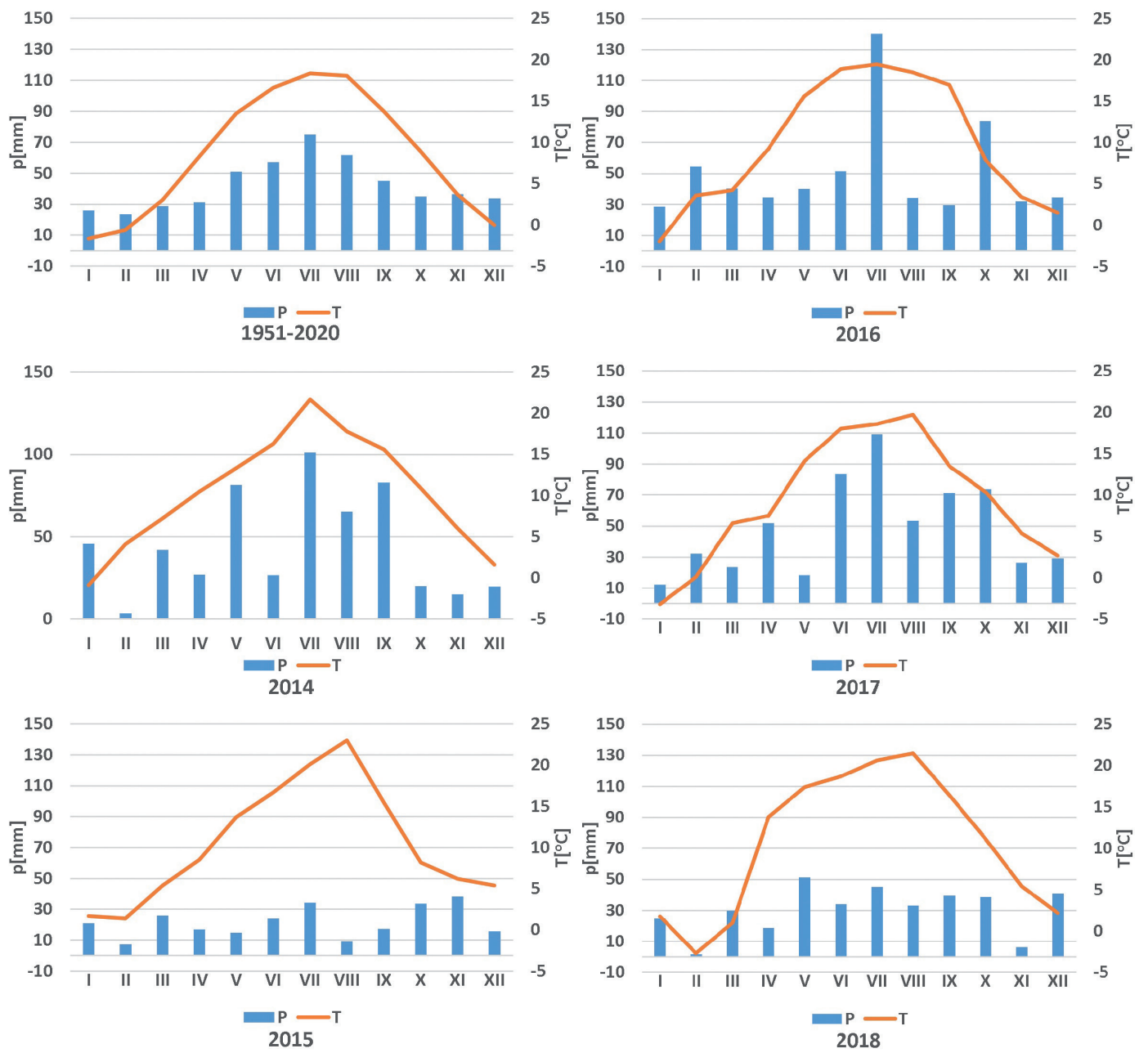

Fig. 2. Left: Monthly precipitation sums (black) and average temperatures (blue) in 2014-2018 measured by Kalisz (Krotoszyn) meteorological station 317. Top Right: Annual precipitation sums (black) in 1951-2018 measured by Kalisz (Krotoszyn) meteorological station 317 (IMGW-PIB 2018). Axis: X - months, Y - Right: temperature [ $\left.{ }^{\circ} \mathrm{C}\right]$, Left: Precipitation [mm]. 


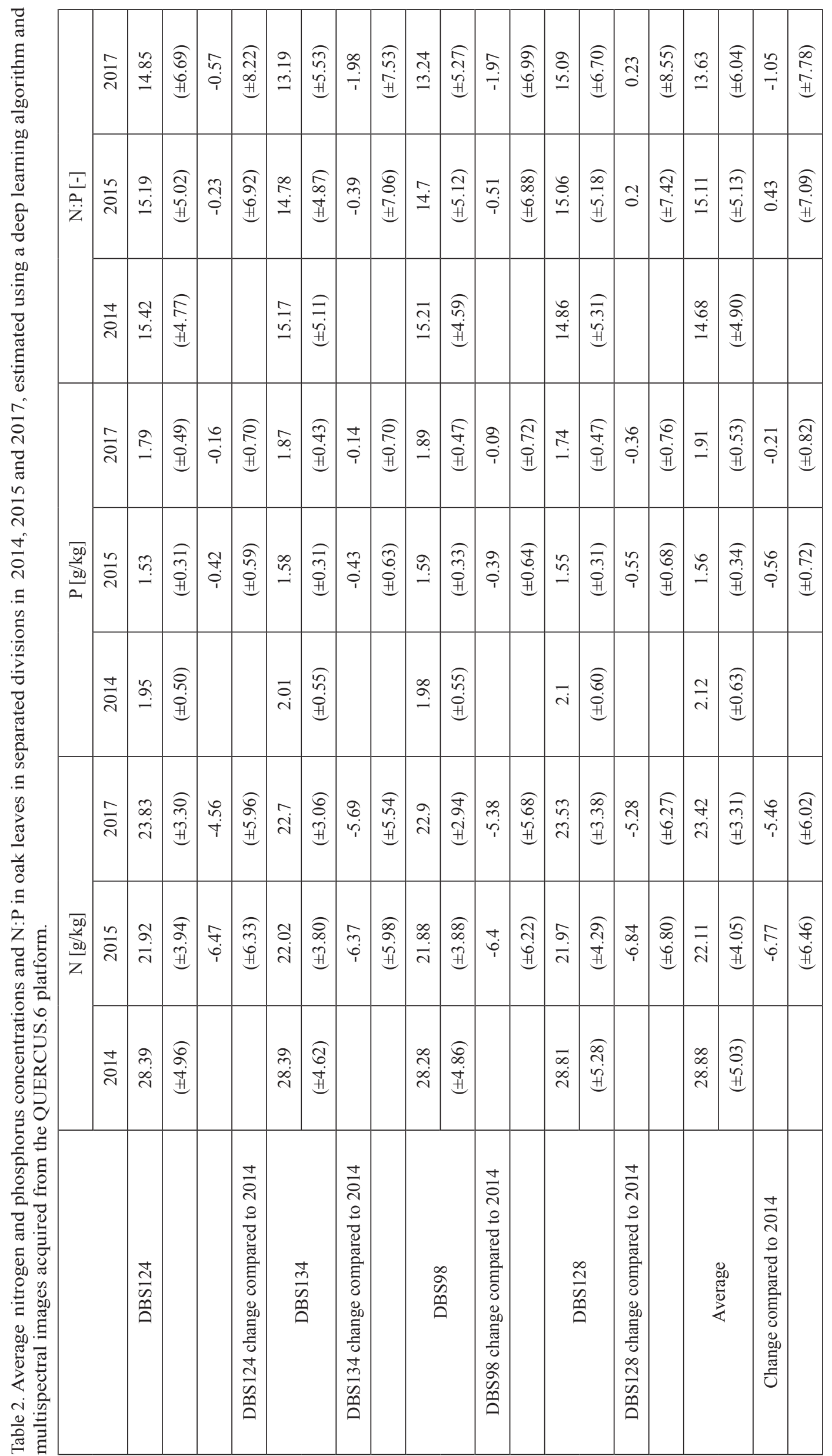


located within the 4 divisions (total area 44.0 ha) of the Forest Data Bank described in Table 1. The machine learning training set for the $\mathrm{P}$ and $\mathrm{N}$ concentrations measured in 2015 and the corresponding remote sensing data are described in Appendix A
Two linear models were determined using the machine learning algorithm. For phosphorus, $\theta_{P}=[0.142$, $0.345,-0.090,0.130,-0.214,-0.219,0.301,-0.021$, $0.053,0.014,-0.079]$ with a cost function of $\mathrm{J}_{P}=0.088$ and for nitrogen $\theta_{N}=[0.164,0.503,-0.065$,
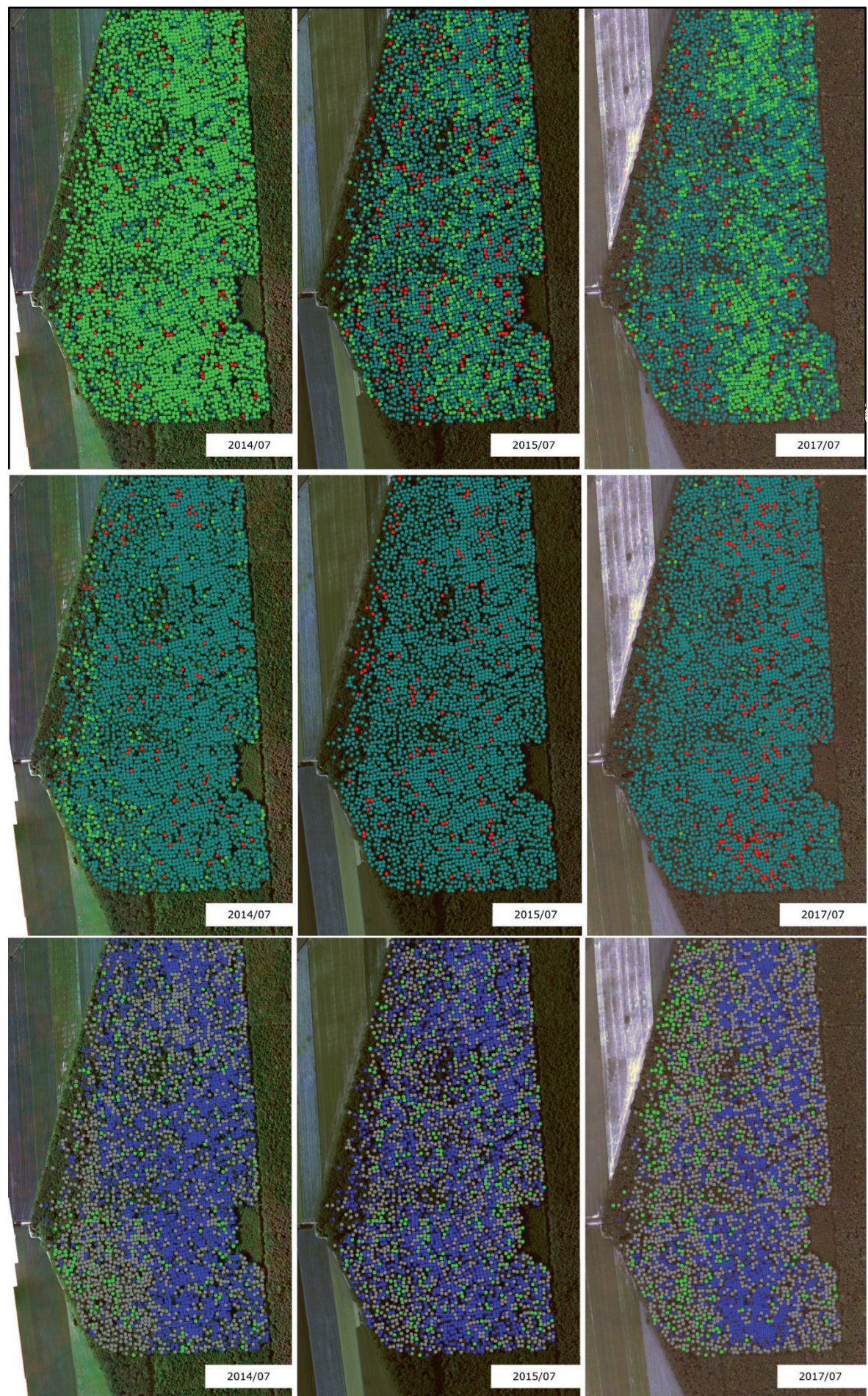

Fig. 3. Top row of pictures: Classification of trees due to the nitrogen concentration in leaves before drought (2014), during short-term drought (2015) and during long-term drought (2017). N concentration: red - below $15 \mathrm{~g} / \mathrm{kg}$, blue $<25 \mathrm{~g} / \mathrm{kg}$, green $>25 \mathrm{~g} / \mathrm{kg}$. Middle row of pictures: Classification of trees due to the phosphorus concentrate on in leaves before drought (2014), during short-term drought (2015) and during long-term drought (2017). P concentration: red - below $1.0 \mathrm{~g} / \mathrm{kg}$, blue- between 1.0 and $3.0 \mathrm{~g} / \mathrm{kg}$, green over $3.0 \mathrm{~g} / \mathrm{kg}$. Bottom row of pictures: Classification of trees due to the N:P value before drought (2014), during short-term drought (2015) and during longterm drought (2017). N:P values: green below 8.33, grey between 8.33 and 15.0, blue over 15.0. 
$0.254,-0.170,-0.095,0.356,-0.151,0.255,0.264,0.185]$, with $\mathrm{J}_{N}=0.252$.

Differences of nutrients content between 2014/2015, 2014/2017 and 2015/2017 (Table 2) are statistically significant for $\mathrm{p}=0.05$ with following 2 exceptions: in division D134 N content difference between 2015 and 2017 is statistically insignificant (test value $=1.39$ ), in division D98 P content difference between 2014 and 2017 is statistically insignificant (test value $=1.24$ ). $\mathrm{N}: \mathrm{P}$ ratio differences between 2014 and 2015 were statistically insignificant for $\mathrm{p}=0.05$ (test values 0.27-0.74). N:P ratio differences between 2014/2017 and 2015/2017 were significant only for D134 and D96 (decreases).

The watershed algorithm separated 4,721 tree crowns with an average area of $21.52 \mathrm{~m}^{2}$. Results obtained from the deep learning algorithm and multispectral images indicate that the $\mathrm{N}$ concentration in oak leaves calculated using equation 1 were on average: $28.88( \pm 5.03) \mathrm{g} / \mathrm{kg}$ in $2014,22.11( \pm 4.05) \mathrm{g} / \mathrm{kg}$ in 2015 and $23.42( \pm 3.31) \mathrm{g} / \mathrm{kg}$ in 2017. Average phosphorus concentrations in the leaves calculated using equation 1 were given as: $2.12( \pm 0.63) \mathrm{g} / \mathrm{kg}$ in $2014,1.56( \pm 0.34) \mathrm{g} / \mathrm{kg}$ in 2015 and $1.91( \pm 0.53) \mathrm{g} / \mathrm{kg}$ in 2017. Leaf $\mathrm{N}$ concentration decreased in all tested forest divisions during drought periods by an average of $6.76( \pm 2.92) \mathrm{g} / \mathrm{kg}$ in 2015 and $5.45( \pm 4.46) \mathrm{g} / \mathrm{kg}$ in 2017. The largest decrease in 2015 was observed in the DBS128 division (average $-6.83 \mathrm{~g} / \mathrm{kg}$ ). The other $\mathrm{N}$ concentration decrease was similar $(-6.37-6.47 \mathrm{~g} / \mathrm{kg})$ for the other three divisions. In 2017, the smallest reduction of $\mathrm{N}$ concentration was observed in leaf samples from the DBS134 division $(-4.55 \mathrm{~g} / \mathrm{kg})$, with the other three divisions experiencing similar decreases (-5.28 up to -5.70) (Table 2, Fig. 3).

Similarly, the $\mathrm{P}$ concentration in oak leaves decreased in all tested forest divisions during drought periods by an of average $0.56( \pm 0.65) \mathrm{g} / \mathrm{kg}$ in 2015 and $0.21( \pm 0.62) \mathrm{g} / \mathrm{kg}$ in 2017. The greatest decrease in 2015 and 2017 was observed in the DBS128 division (average of $-0.55 \mathrm{~g} / \mathrm{kg}$ in 2015 and -0.36 in 2017), with the other three divisions experiencing similar reductions (average of -0.39 up to $-0.42 \mathrm{~g} / \mathrm{kg}$ in 2015 and -0.09 up to $-0.16 \mathrm{~g} / \mathrm{kg}$ in 2017) (Table 2, Figure 3). The nitrogen to phosphorus ratio (N:P) in oak leaves from the divisions DBS124, DBS134, and DBS98 were the lowest in 2014 (average of $15.42 \pm 4.77 ; 15.17 \pm 5.11$ and $15.21 \pm 4.59$, respectively), lowest in 2015 (average of $15.19 \pm 5.02 ; 14.78 \pm 4.87$ and $14.70 \pm 5.12$, respectively) and the lower in 2017 (average of $14.85 \pm 6.69 ; 13.19 \pm 5.53 ; 13.24 \pm 5.27$, respectively). In the DBS128 division, a different situation was observed; $\mathrm{N}: \mathrm{P}$ increased during the observation years. In 2014, an average $14.86 \pm 5.31$ was found, with the ratios in 2015 and 2017 having similar values (average of $15.06 \pm 5.18$ and 15.09 \pm 6.70 , respectively (Table 2, Fig. 3).

It should be mentioned here that the role of machine learning was to estimate the relationship between the observed reflectance and the $\mathrm{N}$ and $\mathrm{P}$ contents in tree leaves measured traditionally. Other parameters such as the content of elements in the soil, soil type etc. have been investigated by traditional methods. While machine learning methods are often used in a broader context, we felt that they should be used with high attention. We used them to link leaf chemistry parameters and leaf reflectance. In this way, we estimated the content of $\mathrm{N}$ and $\mathrm{P}$ in leaves, measured in the laboratory in the training set, for the entire area of the stand. We believe that in the current state of knowledge, the role of machine learning in this task should end.

\section{Machine Learning Model Interpretation}

Nitrogen deficiency in plants is associated with many negative effects, such as growth inhabitation, and the yellowing of the leaves, as a result of disturbed chlorophyll synthesis, disturbance in soil uptake mechanisms, etc., and therefore can be taken as an indirect and relative indicator of the condition of trees. Calculations from the machine learning algorithm model reflect this phenomenon with a positive factor related to the green wavelength $\left(+0.254,4^{\text {th }}\right.$ component of $\left.\vec{\theta}_{N}\right)$. Chlorophyll synthesis reduction also causes a fall in the infrared reflectance (over the "red edge"; the $880 \mathrm{~nm}$ optical band in our case). This observation is also confirmed with the model: a +0.264 factor related to the $880 \mathrm{~nm}$ waveband $\left(10^{\text {th }}\right.$ component of $\left.\vec{\theta}_{N}\right)$. In addition, observed correlations between phosphorus concentration in leaves and the intensity of the photosynthesis [57] reflected in the biomass spectral signatures by increasing the depth of the "red edge" at the red wavelength [61] is observed by the model at the $640 \mathrm{~nm}$ waveband $(-0.219$, $6^{\text {th }}$ component of $\left.\vec{\theta}_{p}\right)$ and the $550 \mathrm{~nm}$ waveband $(+0.130$, $4^{\text {th }}$ component of $\vec{\theta}_{P}$ ).

Nitrogen $(\mathrm{N})$ is a key nutrient for the growth and development of plants as it is involved in the synthesis of chlorophyll, amino acids, nucleic acids and proteins. Water stress can reduce the available $\mathrm{N}$ uptake, resulting in the reduced production of nitrogen compounds [59]. Phosphorus (P) is an important macronutrient that, in addition to its structural function, increases the ability of plants to tolerate drought stress [18, 60]. Phosphorus contributes to the prolongation of the root system and causes modifications of physiological, morphological and biochemical processes, positively influencing plant growth during drought [61-63]. Most of the published studies investigate the relationship between drought stress and $\mathrm{N}$ and $\mathrm{P}$ uptake by agricultural crops plants. Much less attention has been paid to assessing the relationship between drought and conversion of $\mathrm{N}$ and $\mathrm{P}$ in forest trees; an interesting area of research as it is related climate change projections.

\section{Nitrogen and Phosphorus Concentration Decrease: Short-Term Drought Case}

According to the results of metadata analysis published by He and Dijkstra in 2014, the DS effect on $\mathrm{N}$ and $\mathrm{P}$ concentrations was a decrease in concentrations 
by $10.2( \pm 6.2) \%$ and $-18.1( \pm 8.9) \%$, respectively [17]. In our study, a strong effect of drought on nitrogen and phosphorus levels in oak leaves was also observed. The reduction in 2015 of nitrogen and phosphorus was $-24 \%$ and $-26 \%$, respectively, compared to 2014 (without drought symptoms), while the soil amounts for both nutrients were sufficient $(0.14 \mathrm{~N}$ and $4.30 \mathrm{P} \mathrm{g} / \mathrm{kg}$ of soil in 2015). The uptake of nitrogen and phosphorus was disturbed because drought, decreased the soil water availability for external mycelium of mycorrhizal fungi in roots. The efficiency of nutrient uptake from soil is affected by the mycorrhizal community associated with fine roots of trees [64]. Ectomycorrhizal (ECM) communities play key role in belowground carbon flux and turnover, mycorrhizosphere microbial activity, organic matter, and have a significant effect on the ECM communities of oaks (Quercus petrea, Q. robur) throughout Europe [64-66]. ECM can improve nutrient acquisition, particularly phosphorus $(\mathrm{P})$ and nitrogen (N) $[66,67]$. It is still unclear if fluctuations in nutrition availability directly affect the fungi, or whether changes in community structures are mediated via the host plant. Moreover, it has been concluded that nitrogen deposition can alter plant community composition by changing the community of mycorrhizal fungal symbionts [68]. Many studies have shown that the extent of ectomycorrhizal symbiosis within plant roots can be negatively affected by drought, with the effect of this impact noticed in the tree crowns [64, 66, 69].

Changing abiotic conditions can alter the impact of biotic interactions. The cost-benefit ratio of ectomycorrhizal symbiosis varies under different environmental conditions and the host plants regulate their EMF (ectomycorrhizal fungi) partners under changing environmental conditions. Drought, like many other biotic and abiotic stressors, causes changes in the composition of ectomycorrhizal fungi communities. Stressors are driving the dismantling of ectomycorrhizal communities as they have altered the relationship through symbiosis, favoring fungi with low carbon requirements as the host's ability to photosynthesize has been impaired [70]. The characteristics of ectomycorrhizal communities reflect the nutritional needs of their host plants, with communities composed of efficient foragers with high carbon requirements dominating in nutrient deficient soils [71]. For example, the abundance of the mycorrhizal fungus Geopora spp. Was positively associated with the growth of the host plants in a study of trees that experienced drought over an extended period [72]. Also, Passiflora edulis trees that survived the extreme drought were dominated by members of this EMF community [73]. Dismantling ectomycorrhizal communities can be a critical response to stress that favors the host tree and a subset of the mycorrhizal community. The disassembly of the community causes convergence towards several closely related general ectomycorrhizal species, which has negative consequences for the distribution of previously dominant fungi, but may be beneficial for the host plants because the remaining members of the mycorrhizal community were better mutants in the current drought conditions [70, 72].

Our results indicate a greater effect of drought on $\mathrm{N}$ concentrations than in the He and Dijkstra (2014) study $(<-20 \%)$ in all four forest divisions [17]. Under drought conditions, water saturated soil is a reduced chemical environment and may also shift to an oxidized state. During drought, nitrogen can be compromised by micronutrients combining with macronutrients, forming a perfect storm that adds strength to the basic stress effect. Micronutrients help macronutrients to relieve drought by activating certain physiological, biochemical and metabolic processes in the plant. Drought causes an increased production of reactive oxygen substances (ROS) due to the accumulation of energy under plant stress conditions, which causes a photo-oxidative effect and damage to chloroplasts membrane. Macronutrients reduce the toxicity of ROS during drought by increasing the concentration of antioxidant enzymes in the plant cell. These enzymes remove ROS and reduce photooxidation, maintain membrane integrity, and increase the rate of photosynthesis in plants. Micronutrients also increase the concentration of antioxidants and improve the drought tolerance of plants. In other mechanisms, nutrients such as $\mathrm{P}, \mathrm{K}, \mathrm{Mg}$, and $\mathrm{Zn}$ improve root growth, which in turn increases water uptake, which helps regulate the stomata and enhances drought tolerance. Potassium and Calcium help maintain the high water potential of the tissues in conditions of water deficit and improve drought tolerance through osmotic adjustment. Micronutrients such as $\mathrm{Cu}$ and $\mathrm{B}$ mitigate the adverse effects of drought indirectly by activating the physiological, biochemical and metabolic processes taking place in the plant organism. (Role of mineral nutrition in alleviation of drought stress in plants [74].

The soils of oak stands on the Krotoszyn Plateau belong to the Luvisols (stagnosols) class (stagnic luvisosol particular on our test area), with the predominance of clay and low permeable parent rock, characterized by the highest content of $\mathrm{C}$ and $\mathrm{N}$ in surface layers (up to $40 \mathrm{~cm}$ depth), and groundwater at a depth of about $1 \mathrm{~m}[24,75]$. A short but strong drought in 2015 resulted in a reduction of groundwater levels by $2-2.5 \mathrm{~m}$ (local consultation) and was a serious stress factor with the ability to significantly affect the microbial community associated with oak fine roots and nutrition uptake. Studies on the impact of drought on European oaks depending on the type of soil were conducted by $\mathrm{Hu}$ et al in 2015 who observed a varied response of seedlings of three Central European oak species ( $Q$. robur, $Q$. petraea, $Q$. pubescens) for drought depending on the length of its duration and type of soil (in example acidic and calcareous) [79]. In response to droughts, they found an increase of the potassium content and $\mathrm{N}$-soluble $\mathrm{N}$-protein concentration at the expense of structures of $\mathrm{N}$ compounds in the leaves of all three oak species, but the intensity of the stress reaction varied depending on the species and soil. Q. robur was 
the most sensitive to drought stress among the species studied. In all oaks, worse reactions were observed in the acidic soil for drought in comparison to the calcareous. $\mathrm{Hu}$ et al. reported in 2015 that reaction intensity of foliar $\mathrm{N}$ metabolism to the drought-rewetting course was also highly dependent on soil substrate. They also observed that short drought event was not intense enough to induce significant changes, but the repeated drought event applied significantly induced the formation of more $\mathrm{N}$ - soluble protein and amino acids [76].

The dependence between the soil type and the intensity of the Central European oak response to drought stress was also confirmed by a study of Günthardt-Goerg and coauthors in 2013 [77]. On the other hand, some authors did not notice any significant influence of drought and temperature increase on $\mathrm{N}$ content in $Q$. robur and $Q$. petrea leaves observed in Switzerland and no influence of the provinces and soil types [78]. They found that both oaks species tested are less sensitive, because of their distribution covering a wide range of geographical and clear, moderate climate change in Switzerland and moderate global warming will not negatively affect $\mathrm{N}$ and carbon physiology of Q. robur and $Q$. petraea [78].

Two oak divisions with almost the same trees parameters - DBS128 and DBS124 - were characterized by different $\mathrm{N}$ concentrations before drought. The main difference between them is the mixture species: pine, beech and hornbeam in DBS124 and horn- beam, lime and sycamore (A. pseudoplatanus) in DBS128. Interspecific competition during drought stress periods between $A$. pseudoplatanus and the other species results in the reduction of maple [6]. Our results may indicate the same process. Our results have shown that $\mathrm{P}$ concentrations decreased in 2015 by $0.56 \mathrm{~g} / \mathrm{kg}$ (19.9-26.1\% less than observations from 2014). As in the previous case, the highest $\mathrm{P}$ concentration was observed in the DBS128 division and in this case, the highest decrease $(-0.55 \mathrm{~g} / \mathrm{kg})$ was observed. Unlike nitrogen, the highest values in 2014 were observed at a distance of $<50 \mathrm{~m}$ from the cultivated fields in the west part of the forest. The highest $\mathrm{P}$ concentration increase was observed in the divisions DBS98 and DBS132.

The nitrogen to phosphorus ratio $(\mathrm{N}: \mathrm{P})$ for the three divisions DBS124, DBS134, DBS98 decreased in 2015 (compared to results from 2014), while for the DBS128 division, the N:P ratio increased. An increase in the N:P ratio due to drought stress was also observed by [17, 79]. This increase occurs due to the greater reduction in amount of phosphorus leaf levels compared to nitrogen. In contrast, in the study of Herzog and coauthors from 2013, was not observed a fall in P concentrations in pine forests due to drought stress [80].

\section{Nitrogen and Phosphorus Concentration Decrease: Long-Term Drought Case}

We observed an increase $\mathrm{N}$ and $\mathrm{P}$ concentrations in all of the divisions increased in $2017 ; 1.31( \pm 3.53) \mathrm{g} / \mathrm{kg}$ for $\mathrm{N}$ and $0.35( \pm 0.54) \mathrm{g} / \mathrm{kg}$ for $\mathrm{P}$. Yet this was not homogeneous for all forests divisions. According to the nutrient concentrations in 2017, the forests divisions were grouped into two main class: (1) DBS124 and DBS128, characterized by highest $\mathrm{N}$ concentrations $(>23.5 \mathrm{~g} / \mathrm{kg})$, lower $\mathrm{P}$ concentrations $(<1.80 \mathrm{~g} / \mathrm{kg})$ and an N:P index close to 15.0; (2) DBS98 and DBS134 characterized by $\mathrm{N}$ concentrations $<23.0 \mathrm{~g} / \mathrm{kg}, \mathrm{P}$ concentrations $>1.85 \mathrm{~g} / \mathrm{kg}$ and an $\mathrm{N}: \mathrm{P}$ index below 13.5.

It should be noted that the long-term drought stress impact on $\mathrm{N}$ concentrations was the lowest in the DBS124 division (average of $-4.55 \mathrm{~g} / \mathrm{kg}$ in 2017 according to basic 2014 value) and the $\mathrm{N}$ concentration increase between 2015 and 2017 was the highest (average of $+1.91 \mathrm{~g} / \mathrm{kg}$ ). An interesting case is the DBS128 division, which was the most sensitive in terms of shortterm drought stress, yet $\mathrm{N}$ concentrations between 2015 and 2017 also increased also significantly in this division (average of $+1.56 \mathrm{~g} / \mathrm{kg}$ ). We can see that these two similar divisions reacted differently to short-term drought stress, yet similar observations were made for long-term drought stress. We can see in Fig. 3 that in 2017, there were many trees with an optimal $\mathrm{N}$ concentration (over $25 \mathrm{~g} / \mathrm{kg}$ ) on the eastern parts of the two divisions, where drainage ditches are present. It is not possible to observe the dichotomy in the central divisions of the forest, as the area with the drainage ditch is in this division (DBS98) is overgrown with pine trees, not oaks. Our results may confirm the role of forest drainage for nitrogen and water availability [81, 82].

In addition, phosphorus concentration changes are not homogenous. We may observe the longterm drought stress impact on $\mathrm{P}$ concentrations in DBS98, DBS124 and DBS134 as between an average of -0.16 and $-0.09 \mathrm{~g} / \mathrm{kg}$. A different situation is observed in DBS128, as with the short-term drought stress case, $\mathrm{P}$ concentration negative change is stronger : an average of $-0.36 \mathrm{~g} / \mathrm{kg}$. This value is more in line with the short-term drought stress case. As with the nitrogen concentration, we may observe a dichotomy in the DBS124 and DBS128 divisions, but a particularly large number of trees with insufficient $\mathrm{P}$ concentrations (an average of $5.9 \%$ of all trees in the division) was present in the DBS128 division along the drainage ditch (Fig. 3).

\section{Effects on the Composition, Structure, Function and Role of the Forest Ecosystem}

Drought disturbance is an important formation agent of change in forest ecosystem structure and function mediated by vegetation responses. Drought disturbance driver, affecting the existing types of vegetation, as well as their successive stages and vertical structure $[83,84]$. In addition, spatial configuration of landscapes is strongly dependent on interference and changes between disturbing factors and disturbance regimes [83]. Drought contributing to forest mortality has a significant impact on the spatial layout of the forest landscape. Drought disturbance can have also multiple 
impacts on soil conditions affecting the availability of nutrients and the microbial community, including mycorrhizas $[85,86]$ tree's resistance to insect diseases and pests [87]. Mild drought can reduce cell growth, but increases cell differentiation and increase the wall thickness, better protecting the plant from insect pests and diseases $[64,90]$. During a severe drought the content of nitrogen compounds and sugars increases in the plant tissue, increasing the attractiveness of plant tissues for pests [88-90]. Water deficit cause also reduction of concentration of antifungal and antibacterial components in plant tissue increasing of risk infections of by pathogenic fungi [91].

Drought disturbance may have significant effects on the composition, structure, function and role of the forest ecosystem. The response to drought forest stand structure is the result of size species distribution and competition between them through shading and transpiration [92]. Also Yaussy and coauthors in paper from 2012, stressed the importance of competition in determining the impact of drought on the structure of the forest ecosystem because drought does not directly kill trees, its impact on changing competition affects the composition and structure of the forest ecosystem [93]. According to study of Puettmann and Ammer from 2007, drought disturbance can be characterized by the four main criteria include magnitude, severity, frequency, and seasonality of disturbances [94-96]. Presented drought disturbance on Krotoszyn Plateau can be characterized as short- in 2015 and long-term drought in 2016.

For long-term drought, trees subjected to drought stress with low nutritional status are more susceptible to diseases and gradations of insect pests leading consequently to diebacks [83]. In this study, it was shown that forest stands with a predominance of $Q$. robur growing on glial soil during prolonged drought, thanks to compensation mechanisms showed greater tolerance to water stress, showing $\mathrm{N}$ and $\mathrm{P}$ content in leaves greater by $20 \%$ and by $60 \%$ than during short term drought. Our results are consistent with the observations of $\mathrm{He} \&$ Dijkstra for $\mathrm{P}$ concentration, i.e. the long-term drought stress impact on $\mathrm{P}$ concentrations (given as $-1 \%$ by $\mathrm{He} \&$ Dijkstra and $-9.9 \%$ in our study) and for $\mathrm{N}$ concentration the values differ from literature [17]. We observed $19 \%$ reduction of $\mathrm{N}$ concentration in leaves whereas He \& Dijkstra noted $4 \%$ or smaller of nitrogen reduction [17].

Long-term droughts were best tolerated by tree stands in the division DBS134 with Q. robur as a main species and with locally occuring C. betulus, L. decidua, T. cordata) were characterized by the highest nitrogen nutrient status. However, phosphate nutrition due to both short and long-term drought was reduced the most in the DBS128 area. Division DBS134 was characterized by a species composition with a predominance of older trees, whereas in the composition of DBS128 there was younger trees compared to DBS134. Effects of stand composition on resistance to drought is not clear. Previous results indicate that species growing in a mixture are not always less water stressed than those growing in monoculture. The effects of species diversity on tree drought stress are hard to generalize, because different mixtures respond differently depending on the region [89, 90]. But previous, Kotlarz et al. (2018) study in this region indicatedted that highly diverse forests habitats are more suitable to meet the droughts in the context of global climatic changes [24].

Division DBS128 was adjacent to the cultivated field and the proximity of fertilizing the nearby agricultural soil could have an impact on the varied content of nutrients in the forest depending on the supply of rainfall as well as the wind blowing fertilizers from the fields. Scientific report of Dróżdż and coauthors indicate of the existence of an oversupply of mineral nitrogen in these areas mainly with atmospheric precipitation [51]. Excessive nitrogen presence in the soil limits the development of mycorrhiza and therefore the supply of water and trace elements, which affects changes in the share of these elements in reduced tree crowns [9193] on the other hand, phosphorus in soil negatively influences the development of root phytopathogens, e.g. Phytophthora spp. and Armillaria spp. previously found in these stands [94, 95].

The varied response of trees of the duration of drought, expressed by the level of both elements in the leaves, is the result of not only the lack of precipitation or high temperatures of air and soil in the stand, but also by the dysfunction of root systems of trees and mycorrhizal fungi and other elements of the pedosphere. They are responsible for supplying water and mineral compounds to the roots, thus they shape the overall condition of trees and their reactions to changes in the environment [96].

Knowledge and monitoring of the nutritional status of Central European forest stands during the increasingly frequent water deficit and high temperatures in the growing season is important not only due to the recognition of the physiological possibilities of forest species adaptation to changing climatic conditions, but also and mainly, due to maintaining the proper functioning of the entire ecosystem. The forest structure modulated by water availability can change over time due to the emergence of new feedbacks including weather, competition, symbionts of fungi and pathogens, and the effects of drought can be unpredictable [97, 98]. Environmental monitoring tools can be great supportive tools for forest management practices which can partially ameliorate drought impacts through reductions in stand density, selection of drought-tolerant species and genotypes, artificial regeneration, and the development of multistructured stands. However, silvicultural treatments also could exacerbate drought impacts unless implemented with careful attention to site and stand characteristics [97]. Nutrition status of tree stands is connected with the possibility of proper performance of certain stand functions. In the economic, forests it is crucial to 
preserve productivity also during extreamly weather phenomena. The forest divisions examined in this study are forest stands of high importance because of their protective function 317 [35], therefore knowledge about developing tolerance mechanisms for drought when assisting plant nutrition in water deficit gives the possibility of maintaining the proper protective functions of the forest ecosystem. According to above arguments, there is a need to develop better methods for combining the results of observations from different scales, thanks to which it will be possible to determine climate interactions on the size species distribution in the landscape scale [35, 97-102]. Therefore, research with the use of remote sensing application can help in understanding the impact of drought disturbance on the functioning of the ecosystem and the structure of the landscape on a large scale.

\section{Conclusions}

(1) Using laboratory $\mathrm{N}$ and $\mathrm{P}$ concentrations in leaf measurements as a learning set, multispectral aerial images of the whole forest stand, including trees for which measurements were performed and machine learning techniques, it is possible to estimate nutrient concentrations for significantly more trees regarding to 54 trees described in Training Set and observe phenomena for which spatial variability is an important factor.

(2) During drought stress, N concentrations decreased by $23 \%$ in short-term drought stress and by $19 \%$ in long-term drought stress. Luvisol negatively influenced $\mathrm{N}$ concentrations during drought by shifting the reduced chemical environment to an oxidized state, with the occurrence of inter-species competition or was affected by the mycorrhizal community associated with the fine roots of trees.

(3) During drought stress, P concentrations decreased by $27 \%$ in short-term drought stress and by $10 \%$ in long-term drought stress. Our results were consistent with the He \& Dijkstra meta - analysis.

(4) The N:P value increased during short-term drought and decreased during long- term drought, in line with the results of $\mathrm{He} \&$ Dijkstra, however with more stable N:P values ( $+3 \%$ and $-7 \%$ respectively). Our results are applicable to oak monocultures, and conclusions may not be suitable for more diverse forest stands. Recommendation for future research is to study the effectiveness of using machine learning in estimating the concentration of nitrogen and phosphorus in the forest trees in stands with high biodiversity.

\section{Acknowledgments}

This paper has been prepared as a part of the implementation of the HESOFF (LIFE11 ENV/
PL/000459) project, co-financed by the European Commission within the LIFE Instrument.

\section{Conflict of Interest}

The authors declare no conflict of interest.

\section{References}

1. UPGUPTA S., SHARMA J., JAYARAMAN M., KUMAR V., RAVINDRANATH N.H. Climate change impact and vulnerability assessment of forests in the Indian Western Himalayan region: A case study of Himachal Pradesh, India. Climate Risk Management 10, 63, 2015.

2. PAQUETTE A., VAYREDA J., COLL L., MESSIER C., RETANA J. Climate change could negate positive tree diversity effects on forest productivity: a study across five climate types in Spain and Canada. Ecosystems 21 (5), 960, 2018.

3. XU P., ZHOU T., YI C., LUO H., ZHAO X., FANG W., GAO S., LIU X. Impacts of Water Stress on Forest Recovery and Its Interaction with Canopy Height. International journal of environmental research and public health. 15 (6), 1257, 2018.

4. KHAINE I., WOO S.Y. An overview of interrelationship between climate change and forests. Forest Science and Technology. 11 (1), 11, 2015.

5. TOLEDO M., POORTER L., PEÑA-CLAROS M., ALARCÓN A., BALCÁZAR J., LEAÑO C., BONGERS F. Climate is a stronger driver of tree and forest growth rates than soil and disturbance. Journal of Ecology. 99, (1), 254, 2011.

6. PEUKE A.D., RENNENBERG H. 2004. Carbon, nitrogen, phosphorus, and sulphur concentration and partitioning in beech ecotypes (Fagus sylvatica L.): phosphorus most affected by drought. Trees. 18 (6), 639, 2004.

7. ALLEN C.D., MACALADY A.K., CHENCHOUNI H., BACHELET D., MCDOWELL N., VENNETIER M., GONZALEZ P. A global overview of drought and heatinduced tree mortality reveals emerging climate change risks for forests. Forest ecology and management. 259 (4), 660, 2010.

8. DELZON S., URLI M., SAMALENS J.C., LAMY J.B., LISCHKE H., SIN F., PORTÉ A.J. Field evidence of colonisation by Holm oak, at the northern margin of its distribution range, during the Anthropocene period. PloS one. 8 (11), 80443, 2013.

9. SU C.M., HSUEH H.T., TSENG C.M., RAY D.T., SHEN Y.H., CHU H. Effects of nutrient availability on the biomass production and $\mathrm{CO}_{2}$ fixation in a flat plate photobioreactor. Aerosol and Air Quality Research. 17 (7), 1887, 2017.

10. ESTRUCH C., MCFARLAND J., HAW M.P., SCHULZ M.S., PUGNAIRE F.I., WALDROP M.P. Arbuscular mycorrhiza fungi mediate soil respiration response to climate change in California grasslands. In EGU General Assembly Conference Abstracts. 943, 2017.

11. ZAEHLE S., CALDARARU S., EDER L., ENGEL J., KERN M., SCHRUMPF M., WEBER E. Quantifying the effects of interacting nutrient cycles on terrestrial biosphere dynamics and their climate feedbacks. Geophysical Research Abstracts. 19, 13174, 2017. 
12. ANNEX I. Managing the risks of extreme events and disasters to advance climate change adaptation. Sciences. 10, 97, 2012

13. SAXE H., ELLSWORTH D.S., HEATH J. Tree and forest functioning in an enriched $\mathrm{CO}_{2}$ atmosphere. The New Phytologist. 139, 395, 1998.

14. HSIAO T.C. Plant responses to water stress. Annual review of plant physiology. 24 (1), 519, 1973.

15. GESSLER A., SCHAUB M., MCDOWELL N.G. The role of nutrients in drought-induced tree mortality and recovery. New Phytologist. 214 (2), 513, 2017.

16. SANAULLAH M., RUMPEL C., CHARRIER X., CHABBI A. How does drought stress influence the decomposition of plant litter with contrasting quality in a grassland ecosystem? Plant and Soil. 352 (1-2), 277, 2012.

17. HE M., DIJKSTRA F.A. Drought effect on plant nitrogen and phosphorus: a meta-analysis. New Phytologist. 204 (4), 924, 2014.

18. SARDANS J., PEÑUELAS J. The role of plants in the effects of global change on nutrient availability and stoichiometry. Chemoecology. 21, 191, 2011.

19. AERTS R., CHAPIN F.C. III. The mineral nutrition of wild plants revisited: a re-evaluation of processes and patterns. Advances in Ecological Research. 30, 1, 1999.

20. LEHTO T., ZWIAZEK J.J. Ectomycorrhizas and water relations of trees: a review. Mycorrhiza 21 (2), 71, 2011.

21. ALVAREZ M., HUYGENS D., OLIVARES E., SAAVEDRA I., ALBERDI M., VALENZUELA E. Ectomycorrhizal fungi enhance nitrogen and phosphorus nutrition of Nothofagus dombeyi under drought conditions by regulating assimilative enzyme activities. Physiol Plant 136, 426, 2009.

22. DREYER E., BOUSQUET F., DUCREY M. Use of pressure volume curves in water relation analysis on woody shoots: influence of rehydration and comparison of four European oak species. EDP Sciences. 47 (4), 285, 1990.

23. NOORDWIJK M., CREED I.F., JONES J.A., WEI X.A., GUSH M.B., BLANCO J.A., CLAASSEN M. Climateforest-water-people relations: Seven system delineations. In:Forest and Water on a Changing Planet: Vulnerability, Adaptation and Governance Opportunities: A, Global Assessment Report (I.F. Creed and M. van Noordwijk, eds.). IUFRO World Series. 2018.

24. KOTLARZ J., NASIŁOWSKA S.A., ROTCHIMMEL K., KUBIAK K., KACPRZAK M. Species Diversity of Oak Stands and Its Significance for Drought Resistance. Forests. 9 (3), 126, 2018

25. PERKINS D., UHL E., BIBER P., TOIT B., CARRARO V., RÖTZER T., PRETZSCH H. Impact of Climate Trends and Drought Events on the Growth of Oaks (Quercus robur L. and Quercus petraea (Matt.) Liebl.) within and beyond Their Natural Range. Forests. 9 (3), 108, 2018.

26. RODRÍGUEZ-CALCERRADA J., SANCHO-KNAPIK D., MARTIN-STPAUL N.K., LIMOUSIN J.M., MCDOWELL N.G., GIL-PELEGRÍN E. Drought-Induced Oak Decline - Factors Involved, Physiological Dysfunctions, and Potential Attenuation by Forestry Practices. In: GilPelegrín E., Peguero-Pina J., Sancho-Knapik D. (eds) Oaks Physiological Ecology. Exploring the Functional Diversity of Genus Quercus L.. Tree Physiology. Springer, Cham., 7, 419, 2017.

27. BONAL D., PAU M., TOIGO M., GRANIER A., PEROT T. Mixing oak and pine trees does not improve the functional response to severe drought in central French forests. Annals of Forest Science. 74 (4), 72, 2017.
28. ACÁCIO V., DIAS F.S., CATRY F.X., ROCHA M., MOREIRA F. Landscape dynamics in Mediterranean oak forests under global change: understanding the role of anthropogenic and environmental drivers across forest types. Global change biology. 23 (3), 1199, 2017.

29. LIU D., OGAYA R., BARBETA A., YANG X., PEÑUELAS J. Long-term experimental drought combined with natural extremes accelerate vegetation shift in a Mediterranean holm oak forest. Environmental and Experimental Botany. 151, 1, 2018.

30. RUMMUKAINEN M. Changes in climate and weather extremes in the $21^{\text {st }}$ century. WIREs Climate Change. 3, $115,2012$.

31. MICHALSKI J., STARZYK J.R., KOLK A., GRODZKI. Threat of norway spruce caused by the bark beetle ips typographus (1.) In the stands of the forest promotion complex "Puszcza Białowieska" in 2000-2002. Leśne Prace Badawcze. 3, 5, 2004 [In Polish].

32. BEDNARZ Z. Water deficits limits tree ring widths of the oak (Quercus robur L.) in the Niepołomice Forest. Sylwan. 138 (10), 29, 1994 [In Polish].

33. DURŁO G.B., MAŁEK S., SOCHA J. Extreme precipitation events in the Forest Promotion Complex of Silesian Beskid. Folia Forestalia Polonica. 57 (1), 18, 2015.

34. VAN LANEN H., LAAHA G., KINGSTON D., GAUSTER T., IONITA M. Hydrology needed to manage droughts: the 2015 European case. Hydrological Process. 30, 3097, 2016.

35. STANLEY A., CHANGON J.R. Detecting Drought Conditions in Illinois. Illinois State Survey Circular. 164, 1987.

36. SZMYT J. Structural diversity of selected oak stands (Quercus robur L.) on the Krotoszyn Plateau in Poland. Forest Research Papers. 78 (1), 14, 2017.

37. DJAKOW P., Meteomodel, www.meteomodel.pl [access: 03.03.2021]

38. Forests Data Bank; 10. [accessed 2018-10-30]. Available from: bdl.lasy.gov.pl., 2018.

39. CZAPSKI P., KACPRZYK M., KORNILUK T., KOTLARZ J., KUBIAK K., MAZUR A., TKACZYK M. Design and application of multisensory platform for the studies of selected environment characteristics. Prace Instytutu Lotnictwa. 234 (1), 126, 2014 [In Polish].

40. KACPRZAK M., ROTCHIMMEL K. Creating photogrammetry products with photos acquired by array of non-metric cameras. Prace Instytutu Lotnictwa. 243 (2), 120, 2016 [In Polish].

41. STEREŃCZAK K. Single tree detection based on airborne LIDAR (ALS) data. Roczniki Geomatyki. 7 (2), 121, 2009.

42. NGIAM J., KHOSLA A., KIM M., NAM J., LEE H., NG A.Y. Multimodal deep learning. 689, 2011.

43. PEDREGOSA F., VAROQUAUX G., GRAMFORT A., MICHEL V., THIRION B., GRISEL O., VANDERPLAS J. Scikitlearn: Machine learning in Python. Journal of machine learning research. 12, 2825, 2011.

44. WITTEN I.H., FRANK E., HALL M.A., PAL C.J. Data mining: Practical machine learning tools and techniques. San Francisco: Morgan Kaufmann; 2016.

45. NG A.Y., JORDAN M.I. On discriminative vs. generative classifiers: A comparison of logistic regression and naive bayes. Advances In Neural Information Processing Systems. 14, 2002.

46. DIETTERICH T.G. Ensemble Methods in Machine Learning. In: Multiple Classifier Systems. MCS 2000. Lecture Notes in Computer Science, Springer, Berlin, Heidelberg. 1857, 1, 2000. 
47. VAPNIK V.N. An overview of statistical learning theory. IEEE transactions on neural networks. 10 (5), 999, 1999.

48. LOOZEN Y., REBEL K.T., KARSSENBERG D., WASSEN M.J., SARDANS J., PEÑUELAS J., JONG S.M.D.. Remote sensing of canopy nitrogen at regional scale in Mediterranean forests using the spaceborne MERIS Terrestrial Chlorophyll Index. Biogeosciences. 15 (9), 2723, 2018.

49. ZHANG C., DENKA S., COOPER H., MISHRA D.R. Quantification of sawgrass marsh aboveground biomass in the coastal Everglades using object-based ensemble analysis and Landsat data. Remote Sensing of Environment. 204, 366, 2018.

50. BROADHURST D., GOODACRE R., JONES A., ROWLAND J.J., KELL D.B. Genetic algorithms as a method for variable selection in multiple linear regression and partial least squares regression, with applications to pyrolysis mass spectrometry. Analytica Chimica Acta. 348 (1-3), 71, 1997.

51. JONES M.P. Indicator and stratification methods for missing explanatory variables in multiple linear regression. Journal of the American statistical association. 91 (433), $222,1996$.

52. SOKAL R.R., ROHLF F.J. The principles and practice of statistics. San Francisco: WH Freeman and company. 1969.

53. KUTNER M.H., NACHTSHEIM C., NETER J., LI W. Applied linear regression models. McGraw- Hill/Irwin. 2004.

54. DRÓŻDŻ P., DUDZIŃSKA M., HILDEBRAND R., JABŁOŃSKI M., KANTOROWICZ W., KLUZIŃSKI L., ANNA KOWALSKA A., LECH P., MAŁACHOWSKA J., PIERZGALSKI E., PIWNICKI J., STOLAREK A., SZCZYGIEŁ R., ŚLUSARSKI S., TYSZKA J., WAWRZONIAK J., WÓJCIK J., ZAJACZKOWSKI G. Stan uszkodzenia lasów w Polsce w 2014 r. na podstawie badań monitoringowych; Sękocin Stary. Raport opracowany w ramach VI etapu Umowy nr 20/2012/F z dnia 09.08.2012 r. pt. „Monitoring i ocena stanu zdrowotnego lasów w latach 2012-2014”. 2015 [In Polish].

55. BAGHERI V., SHAMSHIRI M.H., SHIRANI H., ROOSTA H. Nutrient uptake and distribution in mycorrhizal pistachio seedlings under drought stress. Journal of agricultural science and technology. 14, 1591. 2012.

56. GOICOECHEA N., ANTOLIN M.C., SÁNCHEZ-DÍAZ M. Influence of arbuscular mycorrhizae and Rhizobium on nutrient content and water relations in drought stressed alfalfa. Plant and soil. 192 (2), 261, 1997.

57. ALAM S.M. Nutrient uptake by plants under stress conditions. In: Handbook of plant and crop stress. 2, 285, 1999.

58. HEIDARI M., KARAMI V. Effects of different mycorrhiza species on grain yield, nutrient uptake and oil content of sunflower under water stress. Journal of the Saudi Society of Agricultural Sciences. 13 (1), 9, 2014.

59. JALEEL C.A., GOPI R., SANKAR B., GOMATHINAYAGAM M., PANNEERSELVAM R. Differential responses in water use efficiency in two varieties of Catharanthus roseus under drought stress. Comptes Rendus Biologies. 331 (1), 42, 2008.

60. LONGSTRETH D.J., NOBEL P.S. Nutrient influences on leaf photosynthesis: Effects of nitrogen, phosphorus, and potassium for Gossypium hirsutum L. Plant Physiology. 65 (3), 541, 1980.

61. HORLER D.N.H., DOCKRAY M., BARBER J. The red edge of plant leaf reflectance. International Journal of Remote Sensing. 4 (2), 273, 1983.
62. ZHONG C., CAO X., HU J., ZHU L., ZHANG J., HUANG J., JIN Q. Nitrogen metabolism in adaptation of photosynthesis to water stress in rice grown under different nitrogen levels. 8, 2017.

63. CORTINA J., VILAGROSA A., TRUBAT R. The role of nutrients for improving seedling quality in drylands. New Forests. 44 (5), 719, 2013.

64. RAZAQ M., ZHANG P., SHEN H.L. Influence of nitrogen and phosphorous on the growth and root morphology of Acer mono. PloS one. 12 (2), 0171321, 2017.

65. FAUSTINO L.I., BULFE N.M., PINAZO M.A., MONTEOLIVA S.E., GRACIANO C. Dry weight partitioning and hydraulic traits in young Pinus taeda trees fertilized with nitrogen and phosphorus in a subtropical area. Tree physiology. 33 (3), 241, 2013.

66. LIU C., WANG Y., PAN K., JIN Y., LI W., ZHANG L. Effects of phosphorus application on photo- synthetic carbon and nitrogen metabolism, water use efficiency and growth of dwarf bamboo (Fargesia rufa) subjected to water deficit. Plant Physiology and Biochemistry. 96, 20, 2015.

67. BRUNNER I., HERZOG C., DAWES M.A., AREND M., SPERISEN C. How tree roots respond to drought. Frontiers in Plant Science. 6, 547, 2015.

68. SUZ L.M., BARSOUM N., BENHAM S., DIETRICH H.P., FETZER K.D., FISCHER R., NEAGU S. Environmental drivers of ectomycorrhizal communities in Europe's temperate oak forests. Molecular Ecology. 23 (22), 5628, 2014.

69. QUEREJETA J., EGERTON-WARBURTON L.M., ALLEN M.F. Topographic position modulates the mycorrhizal response of oak trees to interannual rainfall variability. Ecology. 90 (3), 649, 2009.

70. DICKIE I.A., KOIDE R.T., STEINER K.C. Influences of established trees on mycorrhizas, nutrition, and growth of Quercus rubra seedlings. Ecological Monographs. 72 (4), 505, 2002

71. HILSZCZAŃSKA D., MAŁECKA M., SIEROTA Z. Changes in nitrogen level and mycorrhizal struc- ture of Scots pine seedlings inoculated with Thelephora terrestris. Annals of Forest Science. 65 (4), 1, 2008.

72. KILPELÄINEN J., BARBERO-LÓPEZ A., VESTBERG M., HEISKANEN J., LEHTO T. Does severe soil drought have after-effects on arbuscular and ectomycorrhizal root colonisation and plant nutrition? Plant and Soil. 418 (1-2), 377, 2017.

73. GEHRING C.A., MUELLER R.C., HASKINS K.E., RUBOW T.K., WHITHAM T.G. Convergence in mycorrhizal fungal communities due to drought, plant competition, parasitism, and susceptibility to herbivory: consequences for fungi and host plants. Frontiers in Microbiology 25 (5), 306, 2014.

74. MOELLER H.V., PEAY K.G., FUKAMI T. Ectomycorrhizal fungal traits reflect environmental conditions along a coastal California edaphic gradient. FEMS Microbiology Ecology 87, 797, 2013.

75. GEHRING C., FLORES-RENTERÍA D., STHULTZ C.M., LEONARD T.M., FLORES-RENTERÍA L., WHIPPLE A.V., et al. Plant genetics and interspecific competitive interactions determine ectomycorrhizal fungal community responses to climate change. Molecular Ecology 23, 1379, 2014.

76. SWATY R.L., DECKERT R.J., WHITHAM T.G., GEHRING C.A. Ectomycorrhizal abundance and community composition shifts with drought: predictions from tree rings. Ecology 85, 1072, 2004. 
77. WARAICH E.A., AHMAD R., SAIFULLAH, ASHRAF M.Y., EHSANULLAH. Role of mineral nutrition in alleviation of drought stress in plants. Australian Journal of Crop Science 5, 764, 2011.

78. NASIŁOWSKA S., KACPRZAK M., KOTLARZ J. The impact of drought in 2015 in Poland on the condition oak and pine forests using remote sensing indicators from very high resolution aerial images and OLI. In: $36^{\text {th }}$ EARSeL Symposium; Bonn. EARSEL. 20, 2016.

79. HU B., SIMON J., GÜNTHARDT-GOERG M.S., AREND M., KUSTER T.M., RENNENBERG H. Changes in the dynamics of foliar $\mathrm{N}$ metabolites in oak saplings by drought and air warming depend on species and soil type. PloS one. 10 (5), 0126701, 2015.

80. GÜNTHARDT-GOERG M.S., KUSTER T.M., AREND M., VOLLENWEIDER P. Foliage response of young central European oaks to air warming, drought and soil type. Plant Biology. 15, 185, 2013.

81. LI M.H., CHERUBINI P., DOBBERTIN M., AREND M., XIAO W.F., RIGLING A. Responses of leaf nitrogen and mobile carbohydrates in different Quercus species/ provenances to moderate climate changes. Plant Biology. 15, 177, 2013.

82. SARDANS J., PEÑUELAS J., OGAYA R. Droughtinduced changes in $\mathrm{C}$ and $\mathrm{N}$ stoichiometry in a Quercus ilex Mediterranean forest. Forest Science. 54 (5), 513, 2008.

83. HERZOG C., PETER M., PRITSCH K., GÜNTHARDTGOERG M.S., EGLI S. Drought and air warming affects abundance and exoenzyme profiles of Cenococcum geophilum associated with Quercus robur, Q. petraea and Q. pubescens. Plant Biology. 15, 230, 2013.

84. GROFFMAN P., TIEDJE J. Denitrification in north temperate forest soils: spatial and temporal patterns at the landscape and seasonal scales. Soil Biology and Biochemistry. 21, 613, 1989.

85. NIEMINEN M. Export of dissolved organic carbon, nitrogen and phosphorus following clear-cutting of three Norway spruce forests growing on drained peatlands in southern Finland. Silva Fennica. 38 (2), 123, 2004.

86. ANDREW M.E., RUTHROF K.X, MATUSICK G, J.H.G. Spatial Configuration of Drought Disturbance and Forest Gap Creation across Environmental Gradients. PLoS ONE. 11 (6), 0157154, 2016.

87. TURNER M.G., GARDNER R.H., O'NEILL R.V. Landscape ecology in theory and practice. Springer Verlag, New York, New York, USA. 2001.

88. NAYLOR D., COLEMAN-DERR D. Drought stress and root-associated bacterial communities. Frontiers in Plant Science. 8 (2223), 1, 2018.

89. MILLAR N.S., BENNETT A.E. Stressed out symbiotes: hypotheses for the influence of abiotic stress on arbuscular mycorrhizal fungi. Oecologia. 182 (3), 625, 2016.
90. ANDEREGG W.R., CALLAWAY E. Infestation and hydraulic consequences of induced carbon starvation. Plant Physiology. 112, 2012.

91. MATTSON W.J., HAACK R.A.. The role of drought in outbreaks of plant-eating insects. Bioscience. 37 (2), 110, 1987.

92. WELDEGERGIS B.T., ZHU F., POELMAN E.H. et al. Drought stress affects plant metabolites and herbivore preference but not host location by its parasitoids. Oecologia 177, 701, 2015.

93. KOLB T.E., FETTIG C.J., AYRES M. P., BENTZ B.J., HICKE J.A., MATHIASEN R., WEED A.S. Observed and anticipated impacts of drought on forest insects and diseases in the United States. Forest Ecology and Management. 380, 321, 2016.

94. VOSE J., CLARK J.S., LUCE C, PATEL-WEYNAND T. Effects of drought on forests and rangelands in the United States: a comprehensive science synthesis. General Technical report. WO-93b, 2016.

95. de UÑA L.F., CAÑELLAS I., GEA-IZQUIERDO G. Stand competition determines how different tree species will cope with a warming climate. PloS one. 10 (3), 0122255, 2015.

96. YAUSSY D.A., IVERSON L.R., MATTHEWS S.N. Competition and climate affects US hardwood- forest tree mortality. Forest Science. 59 (4), 416, 2012.

97. PUETTMANN K.J., AMMER C. Trends in North American and European regeneration research under the ecosystem management paradigm. European Journal of Forest Research. 126 (1), 1, 2007.

98. PICKETT S.T.A., WHITE P., Eds. Natural disturbance and patch dynamics: an introduction. In The Ecology of Natural Disturbance and Patch Dynamics, Academic Press, San Diego, 1985.

99. THOMASIUS H. Sukzession, Produktivität und Stabilität natürlicher und künstlicher Waldökosysteme. Archiv für Naturschutz und Landschaftsforschung. 28 (1), 3, 1988.

100. MERLIN M., PEROT T., PERRET S., KORBOULEWSKY N., VALLER P. Effects of stand composition and tree size on resistance and resilience to drought in sessile oak and Scots pine. Forest Ecology and Management. 339, 22, 2015.

101. FORRESTER D.I. Drought responses by individual tree species are not often correlated with tree species diversity in European forests. Journal of applied ecology. 53 (6), 1725, 2016.

102. D'AMATO A.W., BRADFORD J.B., FRAVER S., PALIK B.J. Effects of thinning on drought vulnerability and climate response in north temperate forest ecosystems. Ecological Applications. 23 (8), 1735, 2013. 
